Final version published in:

Progress in Industrial Ecology - An International Journal, Vol. 9, No. 3, 2015

\title{
Connectedness and its dynamics in the Swedish biofuels for transport industry
}

\author{
Carolina Ersson, Jonas Ammenberg* and Mats Eklund \\ Environmental Technology and Management, \\ Linköping University, SE-581 83 Linköping, Sweden \\ *Corresponding Author, jonas.ammenberg@liu.se, +4613281679
}

Biographical notes:

Carolina Ersson is working as a consultant. She was previously a PhD student and holds a licentiate degree. She has written and defended the licentiate thesis: Conditions for resourceefficient biofuels for transport in Sweden.

Jonas Ammenberg is an assistant professor interested in environmental management and environmental systems analysis of biofuels. He is a founder of the Swedish Biogas Research Center (BRC) and is in that context a research area co-ordinator and project leader.

Mats Eklund is a full professor that has initiated and realised research and research education in the fields of material/substance flow analysis, industrial symbiosis and environmental impact assessment. He is now largely involved in biofuel research, being a founder and research leader of the Swedish Biogas Research Center (BRC).

Keywords:

biofuels for transport, biogas, ethanol, biodiesel, production, industrial symbiosis, synergies, energy flows, material flows, connectedness, resource efficiency, business strategy, valorisation, diversification, biorefinery, Sweden, case study

\begin{abstract}
Connectedness through cooperation with other sectors regarding feedstock, energy, products and by-products is important for environmental performance of industrial production. The aim of this study is to provide a better understanding of the level of connectedness in the Swedish biofuels for transport industry, involving producers of ethanol, biogas and biodiesel. In interviews, the CEOs of four important companies provided information about current strategies, historic and planned development. The production systems are dynamic and have changed significantly over time, including material and energy exchanges between traditionally separate industries. Interesting development was noted where revised business strategies have led to changed cooperation structures and thus altered material and energy flows. Fuel and raw material prices are very influential and all of the respondents said that political decisions to a large extent affect their competitiveness and emphasised the importance of clear long-term institutional conditions, ironically very much in contrast to the current situation within EU and Sweden.
\end{abstract}




\section{Introduction}

The EU growth strategy contains demanding challenges - to remain competitive with a growing economy, ensure energy security and simultaneously reduce the climate impact significantly (European Commission, 2011). Several EU member states struggle to reach the 2020 targets (Eurostat, 2013), involving improved energy efficiency and increased use of renewable energy (EU RES, 2009). The transportation sector has major difficulties, lagging behind with a share of renewable energy around 4\% in 2011 (Eurostat, 2013), which is why this article focuses on this sector. To be able to follow the strategy and realize the targets, biofuels are seen as essential solutions (EU RES, 2012, Demirbas, 2009). According to several energy projections and forecasts, biofuels are expected to contribute significantly to the energy supply of the transportation sector for decades to come (OECD/FAO, 2012, BP, 2012, cf. Igliński et al., 2012, Exxon Mobil, 2013). A radically increased production of biofuels for transportation, providing more fuel and reducing the environmental impact, requires resource-efficient biofuel production solutions (Ersson et al., 2013). One important aspect to consider regarding resource efficiency is to what degree biofuel production is integrated with other sectors regarding feedstock, energy supply, and by-products (Martin, 2013, Börjesson, 2009).

Industrial symbiosis (IS) research aims at describing and analysing inter-firm exchanges, dealing with the collaboration between industrial actors and their exchanges of material and energy (Chertow, 2000, Martin and Eklund, 2011). This means their links to suppliers of material and energy and to their customers and other actors such as waste management companies, i.e. analysing the connectedness. Regarding biofuels for transportation, Martin (2013) has investigated the closely related term synergies. For example, Boons et al. (2011) suggest that industrial symbiosis is a process that moves industries towards increased connectedness in terms of material, energy and information flows. Information about physical flows (metabolism) and conditions are essential, but a realisation of resource efficient solutions (implementation of IS) is also very much dependent on economic, institutional and social aspects (Schiller et al., 2014, Domenech and Davies, 2009). The "connectedness concept” has been brought in from the field of biological ecology (Hardy and Graedel, 2002) where ecologists have used both connectedness (or connectance, connectiveness) and diversity to examine the stability, productivity, and functioning of natural communities (Wright et al., 2009). Connectance in biological ecology food webs is a quantitative measure (Hardy and Graedel, 2002) generally defined as the ratio of the number of actual interactions to the number of potential interactions in a community (Wright et al., 2009). A company with several products and many customers can be seen as more resilient than a competitor relying on one major product, mainly sold to a few customers. The diversity of an industrial network is also relevant in this context, for example, considering to what extent it involves organizations of different types (Ruth and Davidsdottir, 2009). In industrial symbiosis literature there is often an underlying assumption that increased connectedness leads to reduced environmental impact (Boons et al., 2011) and increased economic benefits, i.e., “win-win” situations (Karlsson and Wolf, 2008). We do not presume that increased connectedness is always something positive from an environmental or economic standpoint (cf. Boons, 1998, Bergek, 2002, Zhu and Ruth, 2013). However, in assessments of sustainable industrial practices, we claim that it is highly relevant to monitor connectedness and how it is developing, and to analyse this from an environmental and economic perspective. The present biofuel for transport sector is young and growing where rapid development due to market and institutional pressures is to be expected. The 'food versus fuel debate' is influential (Rosegrant and Msangi, 2014) and there is a large focus on environmental performance 
including issues related to land use (Börjesson et al., 2013). Understanding the present situation for biofuel producers and change processes influencing their development is therefore an important component for developing strategies for more sustainable production of biofuels.

The aim of this study is to provide a better understanding of connectedness in the Swedish biofuel industry, focusing on ethanol, biodiesel and biogas producers. Cooperative relations involving material and energy flows, i.e., including raw materials, electricity, heat, products and by-products have been studied, addressing the following questions:

- What is the status of connectedness?

- How has the connectedness changed over the years and what is being planned?

- What critical factors influence this development?

\section{Method}

\section{Studied cases}

For many years, the authors' research group has collaborated with several biofuel companies. During a meeting in 2012, researchers and leading representatives from one ethanol, one biodiesel, and one biogas company discussed future business strategies. Increased valorisation of by-products, further fractionation of feedstock, collaboration projects around energy supply and improvement of $\mathrm{CO}_{2}$ performance were topics mentioned by the companies. This development was interesting, for example, as it stands in contrast to some of the critical global discourse on biofuels (cf. Kuchler and Linnér, 2012). The researchers therefore decided to study this development in the biofuel industry in a more structured and in-depth project, to learn more about these cases and see if similar strategies could be identified in other companies as well. One company each for ethanol and biodiesel was identified and selected for the study together with one private and one municipal biogas company, i.e., four companies representing three different biofuels for transport on the Swedish market.

\section{Collection and analysis of empirical information}

With the main focus on business strategies, the CEO of each company was selected as a respondent. Interviews were performed during the summer and autumn of 2012 in a semistructured manner utilizing an interview guide containing five open questions. Because the study had a descriptive and explanatory approach, open questions were seen as more useful in getting richer narratives than fully structured interviews or a survey would be, even if such studies may be easier to compile.

Initially, the CEOs were asked to illustrate a synoptic input/output scheme for their production plants, focusing on material and energy flows. This was done on paper, and the illustrations facilitated the discussion of the business organization and its dynamics. The illustrations were kept and used to support the transcription and analysis of the recorded interviews. For each company, the 1.5-2 hour interviews were performed face-to-face by the main writer of this article alone or together with one of the co-writers (in two cases). To a small extent, data from literature, or the companies' and their suppliers' websites, have been used as complementary information. Some supplementary information also was acquainted during the validation sessions performed on telephone later in the study. 
All respondents were given the opportunity to check the transcription but only one did so. Therefore, validation questionnaires were sent to the respondents by e-mail. The validation questionnaires did not cover the entire result, but mainly the critical factors for cooperation and strengths of economic and environmental drivers. Only one respondent replied by e-mail, and the others were thus contacted by phone eventually resulting in a validation rate of $75 \%$. The researchers are aware of the fact that it is difficult to separate economic and environmental drivers. The answers indicate that when economic drivers are emphasized it is because of direct economic implications. Environmental drivers also have economic implications for the companies, but more indirectly and long term, for example, related to branding.

Looking at four companies, where differences regarding production methods, location, feedstock, and markets mean varying prerequisites for the level of connectedness, the main part of the analysis is case specific. However, some cross-case analysis was also made, since the study might indicate some general patterns of importance in the biofuel sector. By-product exchanges between the Biodiesel Company (BDC) and the Private Biogas Company (PBC) and the Ethanol Company (EC) and the Municipal Biogas Company (MBC) were found. However, in the coming sections each company is presented individually, without focusing on their inter-relationships. 


\section{The cases}

Some characteristics of the four studied companies are given in Table 1.

Table 1. Overview of the four companies included in this study.

\begin{tabular}{|c|c|c|c|c|}
\hline & $\begin{array}{l}\text { Ethanol } \\
\text { Company (EC) }\end{array}$ & $\begin{array}{l}\text { Biodiesel } \\
\text { Company (BDC) }\end{array}$ & $\begin{array}{l}\text { Municipal } \\
\text { Biogas } \\
\text { Company } \\
(\text { MBC) } \\
\end{array}$ & $\begin{array}{l}\text { Private Biogas } \\
\text { Company } \\
(P B C)\end{array}$ \\
\hline $\begin{array}{l}\text { Date of } \\
\text { establishment }\end{array}$ & 2001 & 2008 & 1992 & 2007 \\
\hline $\begin{array}{l}\text { Year the CEO } \\
\text { was hired }\end{array}$ & 2010 & 2008 & 2010 & 2007 \\
\hline Ownership & $\begin{array}{l}\text { A corporate group } \\
\text { owned by } 35,000 \\
\text { Swedish farmers }\end{array}$ & $\begin{array}{l}8 \text { local farmers, } 75 \% \text {. } \\
\text { Municipal utility } \\
\text { company, } 25 \%\end{array}$ & $\begin{array}{l}\text { Subsidiary to a } \\
\text { large municipal } \\
\text { utility company }\end{array}$ & Privately owned \\
\hline $\begin{array}{l}\text { Number of } \\
\text { plants }\end{array}$ & One & One & $\begin{array}{l}\text { Two (three with } \\
\text { WWTP) }\end{array}$ & Three \\
\hline Type of plants & $\begin{array}{l}\text { Large-scale cereal- } \\
\text { based fermentation } \\
\text { plant }\end{array}$ & $\begin{array}{l}\text { Transesterification of } \\
\text { rapeseed oil to RME }\end{array}$ & $\begin{array}{l}\text { Co-digestion, one } \\
\text { with hygienization } \\
\text { and one without } \\
\text { (and one WWTP) }\end{array}$ & $\begin{array}{l}\text { Co-digestion, one } \\
\text { with hygienization } \\
\text { and two without }\end{array}$ \\
\hline $\begin{array}{l}\text { Overview of } \\
\text { history, } \\
\text { development }\end{array}$ & $\begin{array}{l}\text { 2001: First plant } \\
\text { today accounts for } \\
\text { 25\% of production. } \\
\text { 2008: New, bigger } \\
\text { plant which } \\
\text { accounts for } 75 \%\end{array}$ & $\begin{array}{l}\text { 2007: Small farm-scale } \\
\text { plant. 2010: took over } \\
\text { a large-scale industrial } \\
\text { plant }\end{array}$ & $\begin{array}{l}\text { Initially upgrading } \\
\text { biogas from } \\
\text { WWTP }^{1} 1996: \text { co- } \\
\text { digestion plant. } \\
\text { 2008: thin stillage } \\
\text { plant }\end{array}$ & $\begin{array}{l}\text { Three co-digestion } \\
\text { plants in different } \\
\text { towns in southern } \\
\text { Sweden built 2009, } \\
\text { 2010, } 2011\end{array}$ \\
\hline $\begin{array}{l}\text { Production } \\
\text { capacity }\end{array}$ & $\begin{array}{l}210000 \mathrm{~m}^{3} / \mathrm{y} \\
\text { (capacity and } \\
\text { current production) }\end{array}$ & $\begin{array}{l}110000 \mathrm{~m}^{3} / \mathrm{y} \text { RME } \\
\text { (permitted) }\end{array}$ & $\begin{array}{l}20-22 \text { million } \\
\mathrm{Nm}^{3} / \mathrm{y}^{2} \text { (permitted) }\end{array}$ & $\begin{array}{l}15-18 \text { million } \\
\mathrm{Nm}^{3} / \mathrm{y}^{2} \text { (permitted) }\end{array}$ \\
\hline
\end{tabular}

The studied companies produce biofuel for transport for the Swedish market mainly from Swedish feedstock. The ethanol company (EC) produced about half of the ethanol on the Swedish market in 2011 amounting to 2274 GWh (Swedish Energy Agency, 2012), almost exclusively for low-blend applications. The biodiesel company (BDC) is one of the biggest producers of pure biodiesel (B100) in Sweden, accounting for a minor part of the total biodiesel market of 2183 GWh (ibid.). The limited market means that it makes use of a small part of the production capacity today, but the company has the capacity to cover $100 \%$ of the forecasted Swedish B100 market in 2020 (Svebio, 2012). The municipal biogas company (MBC) is a large-scale producer, and accounted for about $20 \%$ of the total biogas used for transport of 724 GWh in 2011 (Swedish Energy Agency, 2012). Summing up the production of the three plants, the private biogas company (PBC) roughly produces an equal amount of 
biogas. These overall descriptions show that the studied companies are important actors in the Swedish biofuel industry.

\section{Results}

In the following sections the results are presented for each company, mainly structured in relation to questions in the aim.

\section{The Ethanol Company}

The business idea of the ethanol company (EC) was originally to make ethanol from their owners' products (cereals) by contracting local farmers and produce ethanol for low blending in Swedish petrol, and to produce fodder.

\section{What is the status of connectedness for the EC?}

When selecting the location for the EC plant proximity to feedstock, availability of appropriate logistics for the Swedish market and supply of energy with low GHG emissions were important requirements. The flows are shown in Figure 1. When reflecting upon the connectedness, it is important to consider the importance of each flow (or cooperation) and not only the number of flows (also relevant for Figure 2-4). About 85\% of the plant's energy demand is covered by steam from the neighbouring combined heat and power plant (CHP), also producing electricity and district heating from biofuels. The remaining $15 \%$ is electricity. The heat is used for the distillation, but also to dry the by-product of stillage to produce DDGS (Distiller's Dried Grains with Solubles). The DDGS is protein-rich and is put on the market as fodder. The income from the DDGS has increased over the years and today accounts for one-third of the overall income while the ethanol represents the other two-thirds. The business focus has gradually been changing from producing ethanol to producing ethanol and fodder. Most of the feedstock for the ethanol production consists of cereals, mainly winter wheat, of which $80-90 \%$ is produced in Sweden and most of it within a radius of $200 \mathrm{~km}$ from the plant. Even if the feedstock is limited to cultivated starch-rich crops, it involves a large number of local and regional suppliers. In contrast, the ethanol is mainly sold to a few big customers such as oil companies in bulk and distributed all over Sweden.

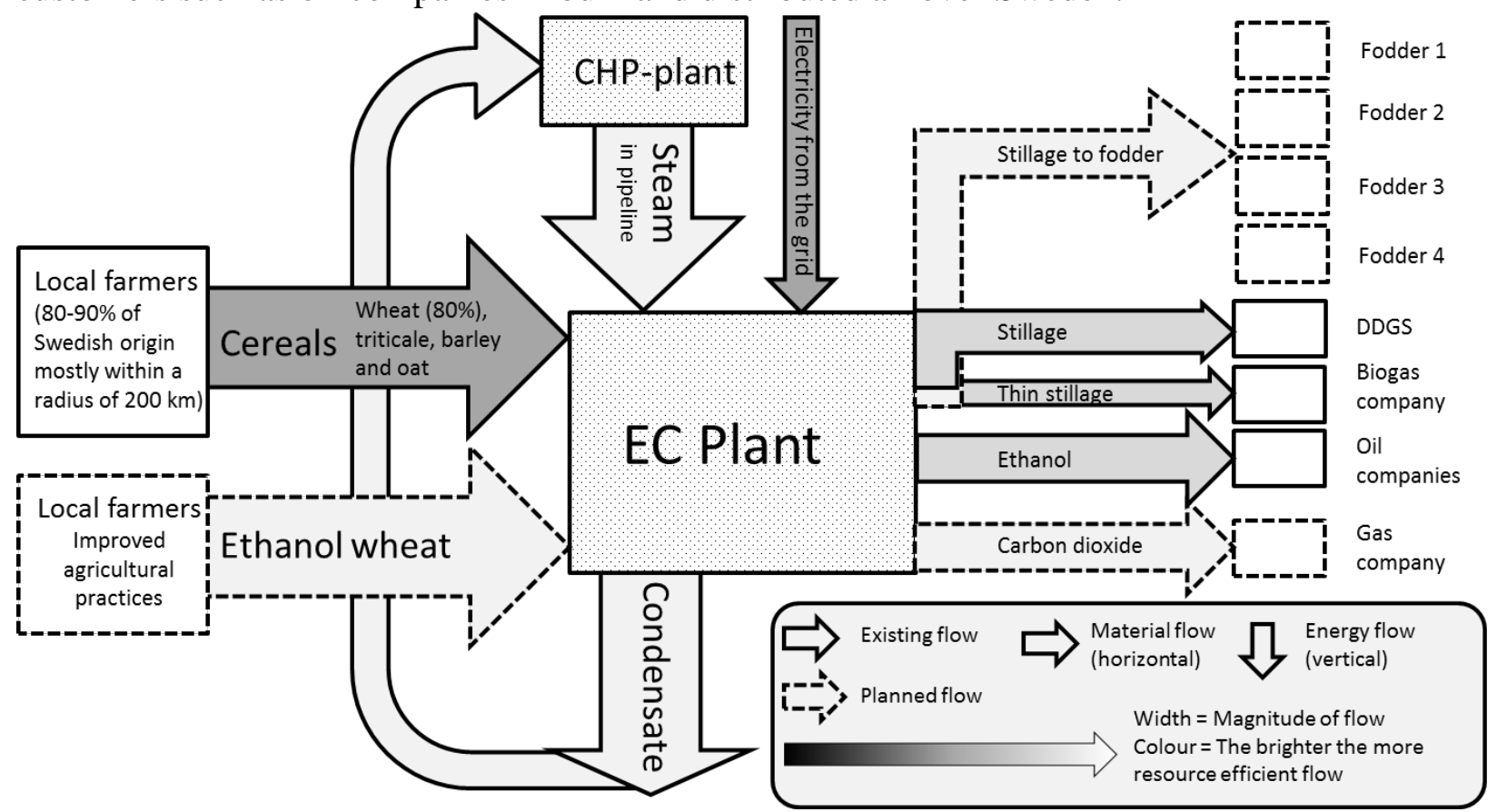

Figure 1. Current and future material and energy flows in the ethanol company. 
The ethanol is currently estimated by the EC to lead to about 70\% reduction of GHGs, compared to petrol and applying a life cycle perspective. Hence this ethanol has a similar climate performance as sugar cane ethanol (EU RES, 2009), often considered the "best" ethanol on the market in this respect.

How has the connectedness in the EC changed over the years and what is being planned? The steam supply from the nearby CHP plant has been ongoing since the start of the EC in 2001. The large expansion of ethanol production in 2008 led to the building of a new biofuel boiler by the CHP plant owner to meet the increased demand. The energy efficiency of the ethanol plant improved and less heat was sent back to the CHP plant. Earlier, the EC sent back heat without economic compensation.

According to the CEO, the strategy of the EC is now to reorganize production in the direction of a biorefinery, also producing several different fodder products with as high value as possible. The stillage has larger potential for improved valorisation than ethanol. The strategy is to separate the stillage into fractions that can be combined into customized products for a range of animals, possibly increasing the willingness to pay. The corporate group, where EC is one division, is among the bigger producers and sellers of fodder in Sweden. Hence a lot of knowledge about fodder and the fodder market exists internally.

Regarding the thin stillage, it was previously delivered to a biogas production plant nearby (the MBC). However, a re-organization as described with a more diversified fodder production will increase the utilization of the stillage internally and reduce the flows supplied to biogas production. However, there will probably be other smaller flows from the new production line suitable for biogas production. Cooperation with a gas sales and distribution company that will capture and clean the biogenic carbon dioxide created in the ethanol distillation is a new joint venture that will further improve the GHG performance of the EC.

Regarding feedstock development, the EC cooperates with the plant breeding division in their corporate group to develop a special ethanol wheat breed with higher starch content and overall yield, but lower protein content. As this breed requires less nitrogen it potentially constitutes an economic win-win concept for local farmers and the EC, also contributing to reduced GHG emissions. Until now the concept has not been largely accepted, due to unsuccessful dissemination in the sales organization and among the farmers.

The EC has not prioritized the relation to the end consumers of the ethanol. Their market for low blending in petrol is controlled by the oil companies, national taxation rules, and custom rules. However they have considered business models where they would get paid for their significantly better GHG emission reduction than the 35\% required in the European Renewable Energy Directive (RED, EU RES, 2009).

What critical factors influence the development of the EC?

Some of the critical factors and drivers for existing and foreseen cooperation are presented in Table 2. 
Table 2. Critical factors and strengths of economic and environmental drivers for the EC's connectedness, i.e., its cooperation related to material and energy flows.

\begin{tabular}{|c|c|c|c|}
\hline Cooperation & Critical factors & $\begin{array}{l}\text { Economic } \\
\text { driver }\end{array}$ & $\begin{array}{l}\text { Environmental } \\
\text { driver } \\
\text { rong } \\
\text { dium } \\
\text { W }\end{array}$ \\
\hline $\begin{array}{l}\text { Green }^{1} \text { steam } \\
\text { from CHP plant }\end{array}$ & $\begin{array}{l}\text { availability of a green reliable energy supplier } \\
\text { policy (RED) } \\
\text { - } \quad \text { no access to the district heating grid } \\
\text { relations and trust due to a long and stable } \\
\text { cooperation } \\
\text { existing pipeline }\end{array}$ & $* * *$ & $* * *$ \\
\hline $\begin{array}{l}\text { Thin stillage to } \\
\text { biogas }\end{array}$ & $\begin{array}{l}\text { need of alternative offset for by-product } \\
\text { business agreement of mutual interest } \\
\text { benefits between the cooperating actors } \\
\text { relations and trust within the biofuel industry }\end{array}$ & * & * \\
\hline Stillage to DDGS & $\begin{array}{l}\text { price of fodder products } \\
\text { residual heat from the processes } \\
\text { impact between products }\end{array}$ & $* *$ & $* *$ \\
\hline Local farmers & $\begin{array}{l}\text { market price for cereals but reduced } \\
\text { transportation costs due to local supply } \\
\text { trust through the cooperative ownership of the } \\
\text { corporate group } \\
\text { policy (RED) criteria such as the traceability } \\
\text { requirement and reduced GHG emissions } \\
\text { (incentive for short transportation) }\end{array}$ & * & $* *$ \\
\hline $\begin{array}{l}\text { Biorefinery }^{2} \\
\text { (valorisation of } \\
\text { by-products) }\end{array}$ & $\begin{array}{l}\text { increased value from fodder products } \\
\text { knowledge on and sales and distribution } \\
\text { organization for fodder in the corporate group } \\
\text { large investments needed to build the } \\
\text { biorefinery }\end{array}$ & $* * *$ & $* *$ \\
\hline Ethanol wheat & $\begin{array}{l}\text { higher yield } \\
\text { lower cost for farmers } \\
\text { policy (RED) high impact of fertilizer on } \\
\text { GHG emissions } \\
\text { farmer business strategy }\end{array}$ & $* *$ & $* * *$ \\
\hline $\begin{array}{l}\text { Biogenic carbon } \\
\text { dioxide capturing } \\
\text { and cleaning }\end{array}$ & 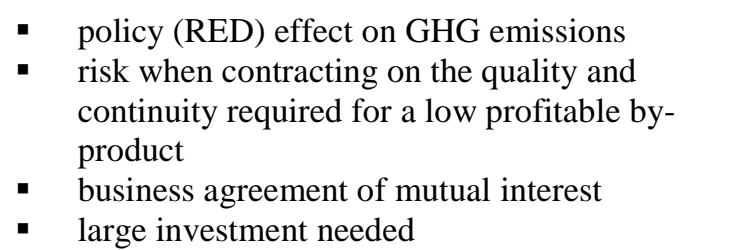 & $*$ & $* * *$ \\
\hline
\end{tabular}

\footnotetext{
${ }^{1}$ Energy production based on a large share of renewable energy

${ }^{2}$ Planned development
}

The economic pressure on the EC is high due to increased cereal prices during recent years coinciding with low ethanol prices. It is difficult to distinguish between economic and environmental drivers and to value their relative strength. However, comparing existing and 
planned cooperative relations in Table 2, the answers from the CEO indicate that both types of drivers are stronger for the biorefinery idea than the "stillage to DDGS" and "thin stillage to biogas" concepts. The biogas company (MBC) cannot pay a competitive price for the thin stillage, which has inhibited this cooperation.

Environmental drivers are important for the new cooperation. The RES directive was mentioned as a critical factor for the biogenic carbon dioxide capturing and cleaning cooperation, expected to have lower (more indirect, long-term) economic implications. There are both strong economic and environmental drivers for the better optimized ethanol wheat breed.

\section{The Biodiesel Company}

The business idea of the biodiesel company (BDC) came from some farmers that wanted to create a company incorporating the whole production chain for biodiesel from rapeseed cultivation to sales and distribution of RME. There were difficulties regarding the production in the original plant, which is why the BDC took the opportunity to take over an operative plant. This plant had an established cooperation with a Vegetable Oil Refinery nearby for which reason the original business idea characterized by independence changed into a more cooperative business organization.

What is the status of connectedness for the BDC?

The cooperation on heating, cooling and rapeseed oil was established before the BDC took over the plant (see flows in Figure 2). Approximately 1/3 of the rapeseed oil produced in the vegetable oil refinery is supplied to the RME production, where the BDC can be seen as taking part in a vegetable oil refinery cluster. The by-products from the oil extraction are processed and sold together with the vegetable oil refinery's other oil crop-based products such as food ingredients, cosmetic products, and technical products. The BDC's RME process starts with pure rapeseed oil and mainly gives one by-product, $13-14 \%$ glycerol, which is currently sold to a biogas company (the PBC) for biogas production.

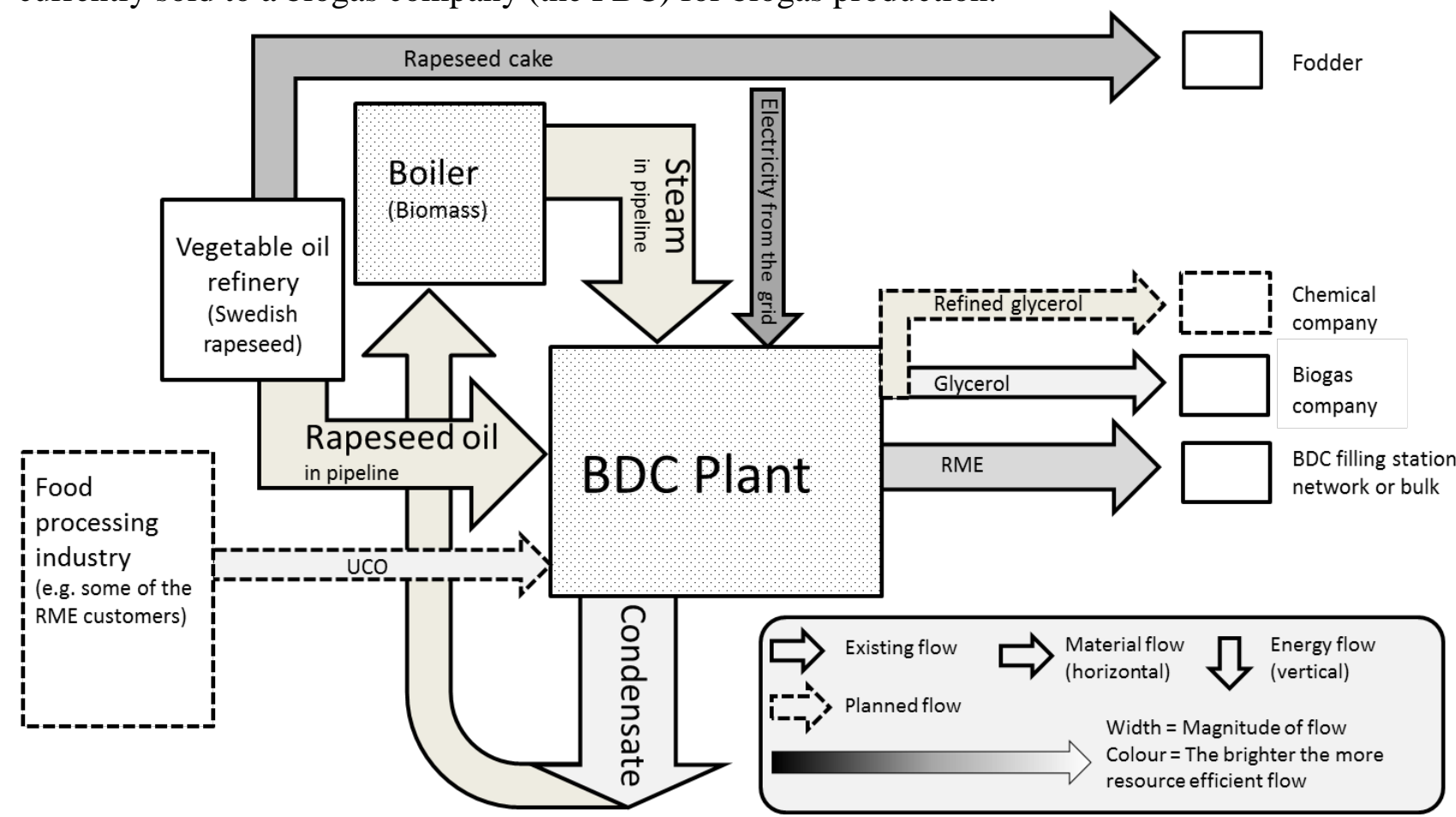

Figure 2. Current and future material and energy flows in the biodiesel company. 
How has the connectedness in the BDC changed over the years and what is being planned? Besides changes caused by moving to the current plant only the glycerol cooperation with the biogas producer is new, initiated by the BDC soon after taking over the RME plant. The CEO emphasized that it is important to be open to new business opportunities and to constantly evaluate the organization. It was stressed that the focus is on expanded production to improve profitability. The volume is too small to really benefit from scale effects. This requires marketing activities, the market for pure biodiesel (B100) in Sweden being too small. Until now the market has had a niche character reliant on a few customer groups and relations since the availability of the fuel has not been good enough for larger customer groups. Also lack of knowledge of B100, its interchangeability with fossil diesel, and about its improved quality in recent years due to technical advances is a problem inhibiting the expansion. Hence the BDC currently focuses on increasing availability, knowledge, and trust by building infrastructure and relations on the local as well as mid-distant markets. Infrastructure projects are particularly expensive and are performed in a joint investment project with a big truck manufacturing company which will result in a filling station network for B100 in southern Sweden. Possibly this will also contribute to increase interest and trust among truck drivers which were seen as a large but rather conservative potential customer group.

The cooperation around rapeseed oil with the vegetable oil refinery is well functioning and is not foreseen to change. However, in case of radically expanded production the BDC cannot take a corresponding increased supply from this refinery for granted. A complementary feedstock is desirable and one opportunity could be used cooking oil (UCO). Some current B100 customers get used cooking oil as a by-product (e.g. fast food chains) and have indicated an interest in cooperation around it. The BDC also considers other options regarding the glycerol (now used for biogas production), to refine it into other products.

What critical factors influence the development of the BDC?

Some of the critical factors and drivers for the existing and foreseen cooperation are presented in Table 3. 
Table 3. Critical factors and strengths of economic and environmental drivers for the BDC's connectedness, i.e., its cooperation related to material and energy flows.

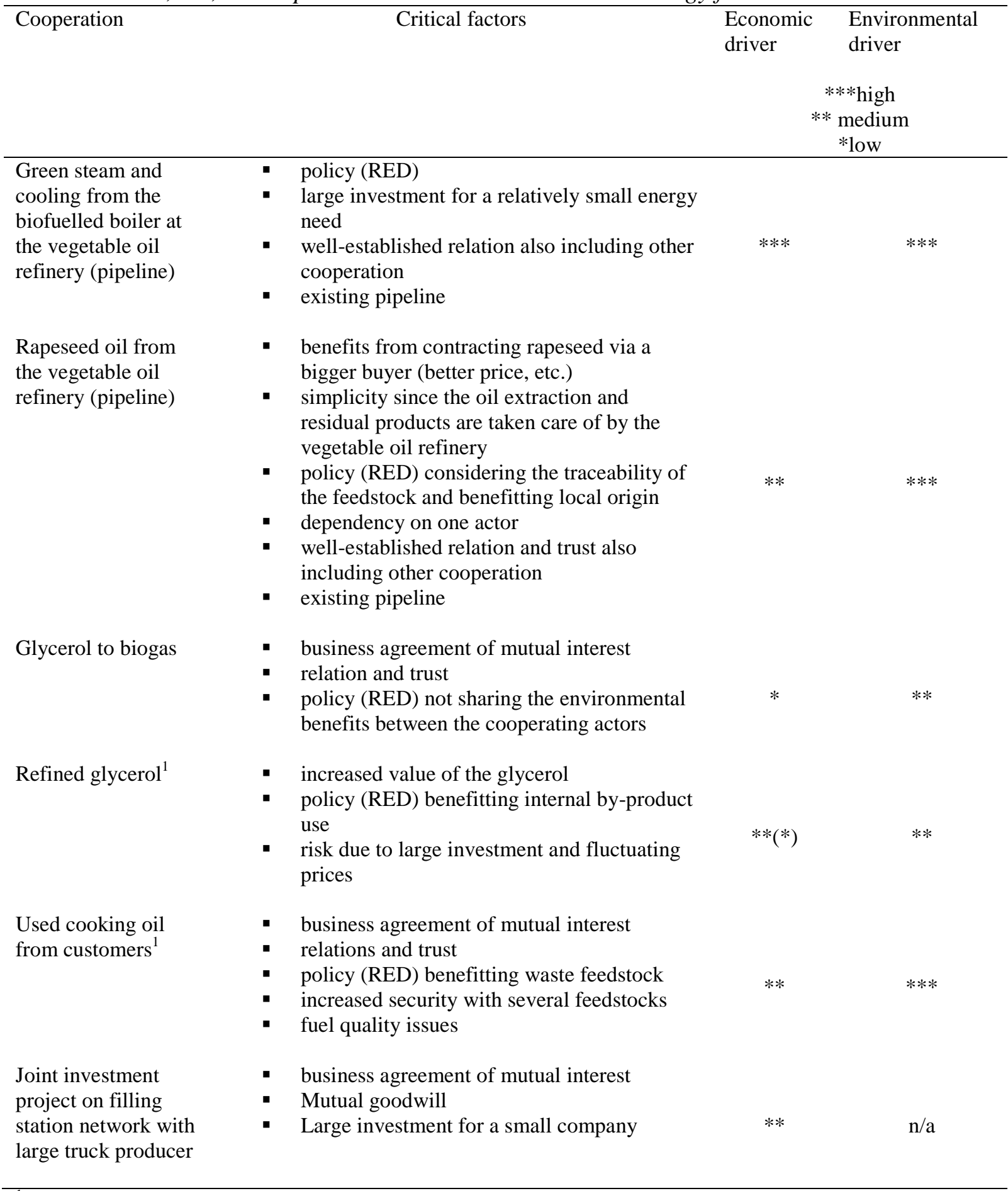

${ }^{1}$ Planned development

According to the CEO, many of the customers use B100 because it is economically favourable. However, the environmental driver was seen as strong for all cooperative relations, glycerol being one exception (see Table 3).

The BDC has a close cooperation with the refinery supplying the oil and a large share of the energy. Trust has developed due to a long-term relation which seems to be important for this 
cooperation. The CEO emphasized the importance to of cultivating this relation. Also, existing infrastructure such as pipelines are important for this cooperation.

Regarding the glycerol an earlier business relation seems to have been the initiator of the cooperation and trust has developed over time. However, if the BDC refines the glycerol this cooperation will cease. The European Renewable Energy Directive (RED) is of importance as it decides how environmental impact can be shared. As long as the glycerol is used for biogas production, the BDC cannot allocate any of its environmental impact to that process. Conversely, if it is refined internally and then, for example, sold for production of cosmetics some of the environmental impact for B100 can be allocated to those products. The RED was mentioned as a critical factor for other cooperation as well.

As expected, the economic drivers are strong for initiatives to expand the filling station network and stimulate the market.

\section{The Municipal Biogas Company}

The Municipal Biogas Company (MBC) was a pioneer in the biogas for transport industry in Sweden and the development was encouraged by the search for alternative fuel for public buses (Fallde, 2011, Berglund, 2011). The business idea was originally to produce biogas for public and private transport (buses and cars), and provide a resource-efficient waste handling service for difficult wastes such as waste from a local slaughterhouse.

What is the status of connectedness for the MBC?

Figure 3 shows the main flows. The heat is supplied as an intra-firm cooperation within the MBC's corporate group, from a nearby biofuelled CHP plant via the district heating grid that was established from the start. The industrial food waste from the slaughterhouse has been a large and important flow for a long time. Glycerol and thin stillage are by-products supplied from biodiesel and ethanol production respectively. The digestate, or biofertilizer, cooperation involves a consultancy firm besides the farmers being the end-users. The fertilizers are transported and spread on local farmland (partly certified for organic farming). 


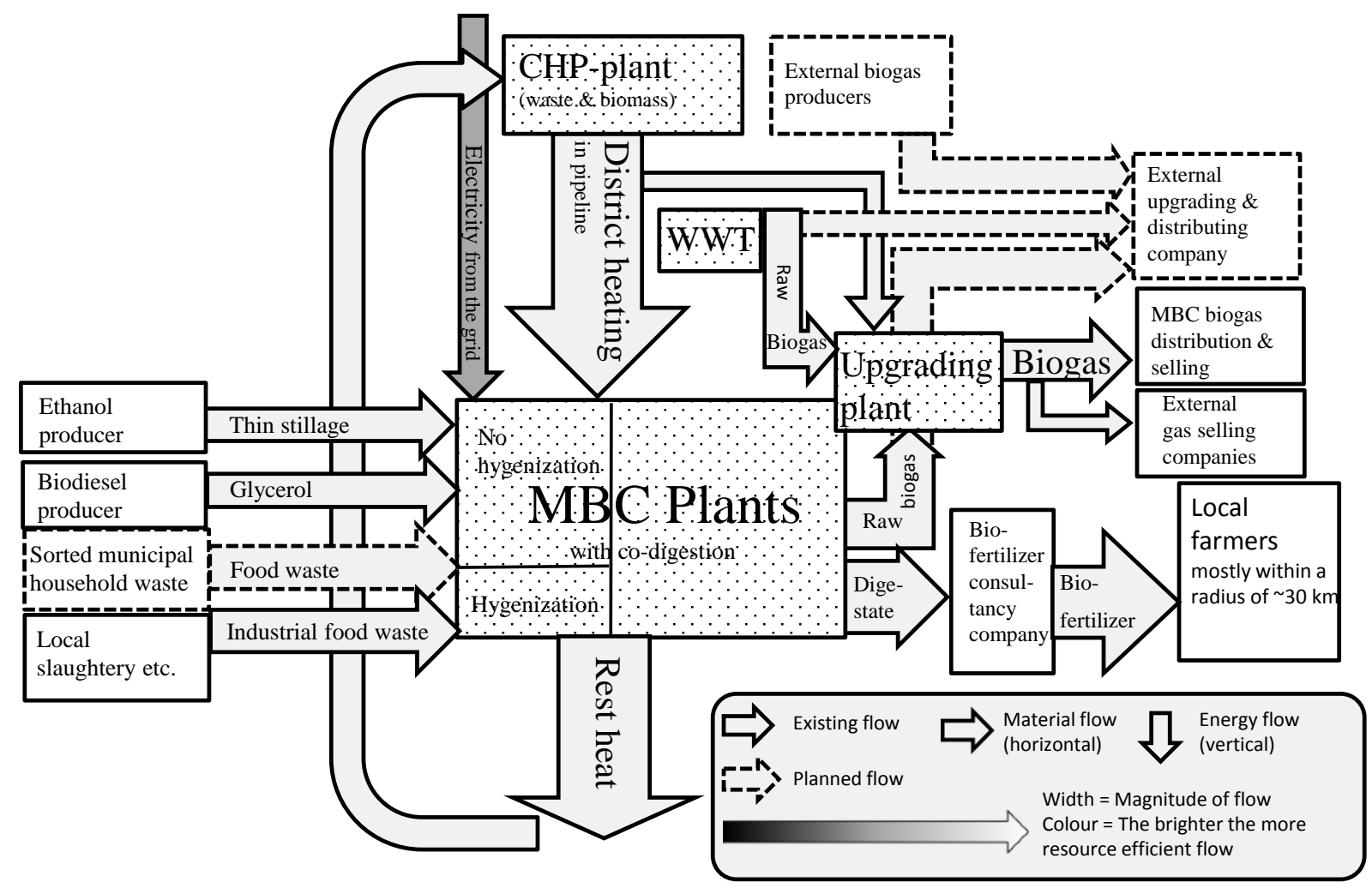

Figure 3. Current and future material and energy flows in the municipal biogas company. Note that flows of two co-digestion plants are merged into one illustration and that biogas is also produced from sewage sludge within the waste water treatment plant (WWT).

How has the connectedness in the MBC changed over the years and what is being planned? The district heating grid has been extended also to supply heat for the biogas upgrading. The slaughterhouse waste is classified as hazardous and must be hygienized if the digestate is to be used as biofertilizer, implying a higher energy need, which is why the cooperation around district heating is important. Lately, the main flow of slaughterhouse waste has been complemented by food waste from sorted household waste. The amount and quality of the food waste relies on individuals' willingness to sort their waste which complicates the cooperation since this is done entirely on a voluntary basis.

Biofertilizer handling is an essential part of biogas production systems and can influence the economic and environmental performance substantially. The cooperation with the consultancy firm for distribution and sale of the biofertilizer was initiated to enable better cooperation with the end-users and to improve the profitability which was often a "zero sum game". According to the CEO the consultancy firm provides essential competence and functions not seen as the core business of the MBC. It has become easier to find offset for the biofertilizer especially in the case with the eco-certified biofertilizer produced in one of the plants, but profitability is still low mostly due to the costly transportation and storage.

As described for the ethanol company the cooperation regarding thin stillage may cease.

Due to the small organization the MBC is considering splitting off gas sales and distribution. Such splitting would also allow the sales and distribution company to grow outside the municipal boundaries since the operation would not be restricted by the regulations of municipal companies where administrative boundaries are important. Possibly this would also 
give better opportunities for decentralized biogas production, e.g. farm-scale production, because the upgrading and infrastructure is a big barrier for small-scale biogas production according to the CEO. Cooperation on these functions might in some cases make small-scale biogas production economically feasible enabling the use of substrates not suitable for transportation to a centralized production unit, e.g. manure.

What critical factors influence the development of the MBC?

Some of the critical factors and drivers for the existing and potential cooperation are presented in Table 4.

Table 4. Critical factors and strengths of economic and environmental drivers for the MBC's connectedness, i.e., its cooperation related to material and energy flows.

\begin{tabular}{|c|c|c|c|}
\hline Cooperation & Critical factors & $\begin{array}{l}\text { Economic } \\
\text { driver }\end{array}$ & $\begin{array}{l}\text { Environ- } \\
\text { mental } \\
\text { driver }\end{array}$ \\
\hline & & \multicolumn{2}{|c|}{$\begin{array}{l}* * * \text { strong } \\
* * \text { medium } \\
\quad * \text { low }\end{array}$} \\
\hline $\begin{array}{l}\text { district heating } \\
\text { grid (one of the } \\
\text { plants) }\end{array}$ & $\begin{array}{l}\text { - } \quad \text { availability of a green reliable energy supplier } \\
\text { - } \quad \text { available gas upgrading technology based on } \\
\text { heat }\end{array}$ & $* * *$ & $* * *$ \\
\hline $\begin{array}{l}\text { Industrial food } \\
\text { waste (e.g. } \\
\text { slaughterhouse } \\
\text { waste) }\end{array}$ & $\begin{array}{l}\text { - } \text { adequate waste treatment service } \\
\text { - } \text { available gate fee for waste } \\
\text { - } \quad \text { policy (RED) benefit waste/by-product feedstock } \\
\text { - } \quad \text { relations and trust to food industry in proximity } \\
\text { competitive market on valuable wastes for } \\
\text { biogas production }\end{array}$ & $* * *$ & $* * *$ \\
\hline $\begin{array}{l}\text { Thin stillage from } \\
\text { ethanol } \\
\text { production (one of } \\
\text { the plants) }\end{array}$ & $\begin{array}{l}\text { - } \quad \text { existing plant designed for thin stillage } \\
\text { - } \quad \text { price of fodder products } \\
\text { policy (RED) not sharing the environmental } \\
\text { benefits } \\
\text { - } \quad \text { valuable biofertilizer certified for organic } \\
\text { farming }\end{array}$ & $*$ & $* *$ \\
\hline $\begin{array}{l}\text { Digestate used as } \\
\text { biofertilizer }\end{array}$ & $\begin{array}{l}\text { - large quantities of digestate that need offset } \\
\text { - } \quad \text { expensive storage, transportation and spreading } \\
\text { - } \quad \text { complete fertilizer product with micro and macro } \\
\text { nutrients and organic matter } \\
\text { - } \quad \text { nutrient recycling (environmental goals) }\end{array}$ & $*$ & $* * *$ \\
\hline $\begin{array}{l}\text { Food waste from } \\
\text { households }^{1}\end{array}$ & 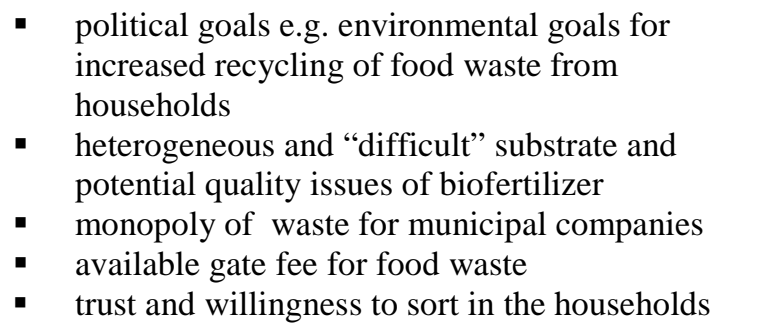 & $* *$ & $* * *$ \\
\hline $\begin{array}{l}\text { Splitting into } \\
\text { production and } \\
\text { sales \& } \\
\text { distribution }\end{array}$ & $\begin{array}{l}\text { - production of biogas is the core business of the } \\
\text { company and the sales and distribution } \\
\text { organization is already too big } \\
\text { - } \quad \text { restrictions for municipal companies e.g. }\end{array}$ & $* *$ & $\mathrm{n} / \mathrm{a}$ \\
\hline
\end{tabular}




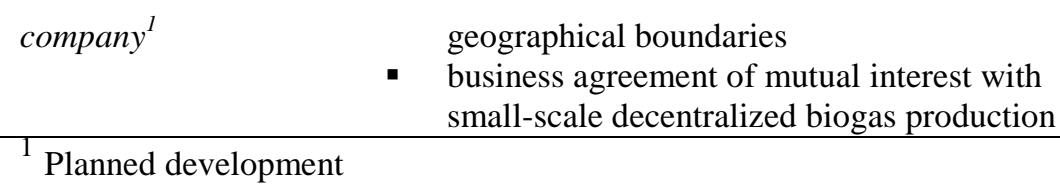

${ }^{1}$ Planned development

For most feedstock the MBC receives a gate fee for the waste treatment service, but for some substrates they pay, e.g. glycerol and thin stillage. For the food waste from households they also receive a gate fee since the households pay for the waste collection and treatment.

The use of waste or by-product feedstock is benefitted by the RED, but other regulations like the EU waste directive and in the case of food waste the national environmental goals are also driving forces. Regarding the use of biofertilizer the same policies are pushing for this cooperation but the economic driver for the MBC is so low that it is problematic. Striking in the MBC case is the expressed concern about profitability despite having revenues from gate fees for almost all their substrates. The economic driver for food waste is rated as medium, but according to the CEO this feedstock is good on the margin but would not be economically feasible with that substrate only because it is a heterogeneous and "difficult" substrate compared for instance to slaughterhouse waste or thin stillage. Not surprisingly, the cooperative relations where both the economic and environmental drivers are strong seem to be the most stable and long term, i.e., regarding district heating and the slaughterhouse waste.

\section{The Private Biogas Company}

The business idea of the PBC is to tie a cooperative network of actors together around a few production plants in Sweden (potentially also internationally) where the conditions for biogas production is favourable.

What is the status of connectedness for the PBC?

All three existing plants were established by using a business model where certain cooperative relations were set, seen as crucial for the establishment of a new plant and implying cooperation with several actors. Some projected plants have been suspended due to difficulties in establishing some essential cooperation.

Some feedstock categories are similar to the MBC, but the supplied material includes not only waste or by-products, but also agricultural feedstock such as ley crop (dedicated crop). Biogas is also produced from manure. In contrast to the MBC, the PBC pays for most of the raw material.

In Figure 4 the main flows are presented for the three plants. 


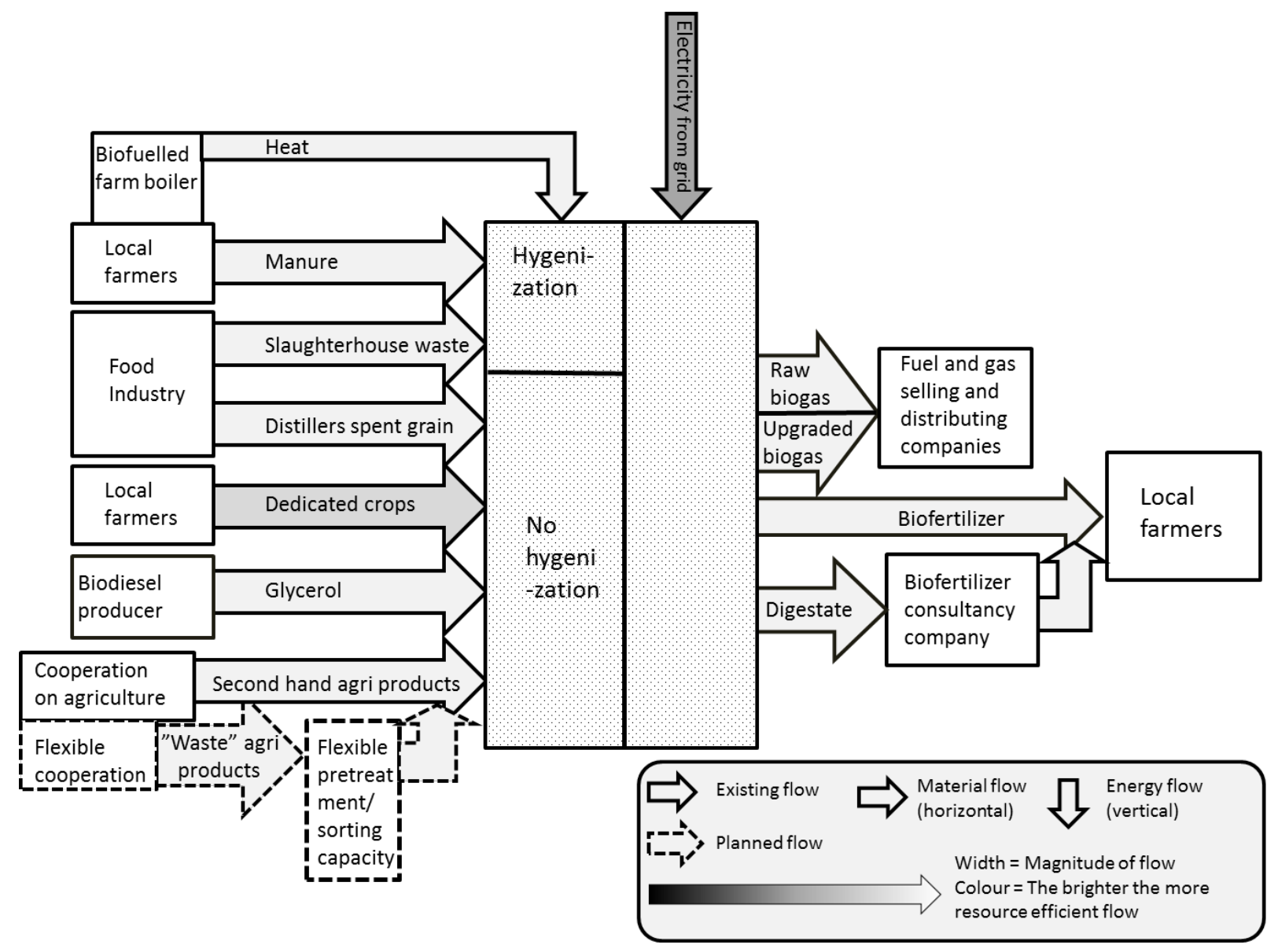

Figure 4. Current and future material and energy flows for the Private Biogas Company. Note that flows of three plants are merged into one illustration.

Agricultural feedstock is a challenge since it is often distributed among many small actors. In the plant where manure is used the solution was to create a certain joint estate manure company coordinating the manure and biofertilizer handling between the actors which simplified business administration radically. The biofertilizer from one of the other two plants is handled through the same consultancy company the MBC uses, while in the last plant it is more or less self-organizing. The differences in biofertilizer distribution have developed to a large extent due to the local conditions such as feedstock, branch of farm production structure and types of soil, but also on relations and trust between actors.

Since the manure plant needs energy demanding hygienisation, due to the substrates used, a joint investment in a new biofuelled boiler with one of the farmers in need of a new crop dryer was mentioned as important. The glycerol supply from biodiesel producers is small as it is considered expensive. However, it is an important flow due to its production-regulating capacity.

How has the connectedness in the PBC changed over the years and what is being planned? The CEO emphasized that an important condition for a plant is a long-term contract with customers for the biogas. From that, based on available feedstock, the organization is established. Regarding the supply of feedstock a paradoxical situation was noted. Long-term contracts assure access to feedstock which is an important condition. However, the respondent 
indicated that it has become more difficult, and more expensive, to get long-term contracts on by-products from industry, for instance since the suppliers want to keep different options open as the market is dynamic. Consequently, the PBC is changing strategy to reduce the share of long-term contracted feedstock, requiring flexible plants, being able to digest several types of feedstock.

What critical factors influence the development of the PBC?

Some of the critical factors and drivers for the existing and planned cooperation are presented in Table 5.

Table 5. Critical factors and strengths of economic and environmental drivers for the PBC's connectedness, i.e., its cooperation related to material and energy flows.

\begin{tabular}{|c|c|c|c|}
\hline Cooperation & Critical factors & $\begin{array}{l}\text { Economic } \\
\text { driver }\end{array}$ & $\begin{array}{l}\text { Environmental } \\
\text { driver } \\
\text { rong } \\
\text { dium } \\
\text { W }\end{array}$ \\
\hline $\begin{array}{l}\text { Green heat from biofuelled } \\
\text { farm boiler (one of the } \\
\text { plants) }\end{array}$ & $\begin{array}{ll}\text { - } & \text { opportunity for green heat cooperation } \\
\text { - } & \text { policy (RED) } \\
\text { - } & \text { business agreement of mutual interest } \\
\text { - } & \text { relation and trust due to the } \\
& \text { cooperation with farmers at this plant }\end{array}$ & $* * *$ & $* * *$ \\
\hline $\begin{array}{l}\text { Industrial food waste (e.g. } \\
\text { slaughterhouse waste etc.) }\end{array}$ & $\begin{array}{l}\text { - } \text { adequate waste treatment service } \\
\text { - } \quad \text { relicy (RED) benefits waste feedstock } \\
\text { - competitive market on valuable wastes } \\
\text { for biogas production } \\
\text { good complement to the manure } \\
\text { feedstock }\end{array}$ & $* *$ & $* * *$ \\
\hline $\begin{array}{l}\text { Industrial food by-products } \\
\text { (e.g. distillers spent grain, } \\
\text { starch, buttermilk, second- } \\
\text { rate grain, etc.) }\end{array}$ & 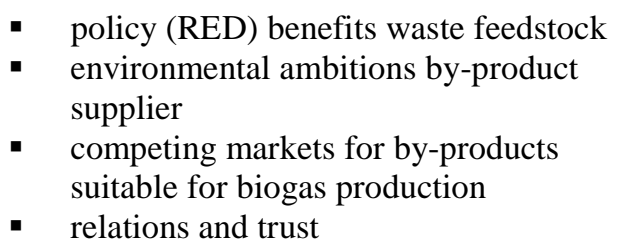 & * & $* * *$ \\
\hline $\begin{array}{l}\text { Glycerol from biodiesel } \\
\text { production }\end{array}$ & $\begin{array}{l}\text { - } \quad \text { efficient feedstock ideal for regulating } \\
\text { the biogas production } \\
\text { - } \quad \text { policy (RED) not sharing } \\
\text { environmental benefits } \\
\text { - } \quad \text { competing markets for this substrate } \\
\text { - } \quad \text { relation and trust }\end{array}$ & $*$ & $* *$ \\
\hline $\begin{array}{l}\text { Dedicated (ley) crops for } \\
\text { biogas production }\end{array}$ & 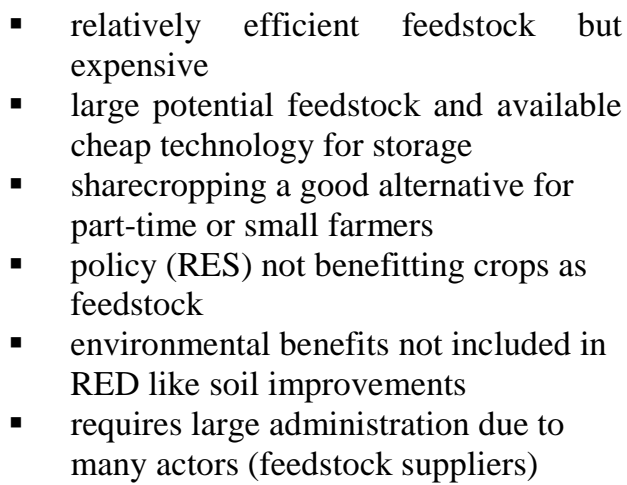 & * & $*$ \\
\hline
\end{tabular}


Hog manure

Digestate used as biofertilizer

Gas sales and distribution company

Flexibility on feedstock ${ }^{1}$
- low-efficiency feedstock but large potential

- policy (RED) benefits waste feedstock

- mutually beneficial barter exchange agreement on feedstock and biofertilizer

- no methane reduction subsidy available

- the formation of a manure handling company

- relation and trust

- large quantities of digestate that needs offset

- expensive storage, transportation and spreading

- relations and trust

- complete fertilizer product with micro and macro nutrients and organic matter

- nutrient recycling (environmental goals)

- secured market at a fixed price

- simplicity increasing the ability to focus on the core business

- access to new technology for upgrading and compression (e.g. LBG)

- no relation and trust building with end users

- efficient biogas substrates to low price

- investment and operational costs for sorting and pretreatment facilities

- policy (RED) benefits waste feedstock

- administration working with the search for and contracting of the feedstock

- relation and trust building

\footnotetext{
${ }^{1}$ Planned development
}

The cooperation on biogas is fixed due to the long-term contracts, often up to 10 or 15 years, with a sales and distribution company. This sets essential frames for the revenues - a longterm market and a fixed price. The digestate sales and distribution is contracted only in the manure plant, where it is a barter exchange agreement. All the biofertilizer in all plants however is distributed, but often without long-term contracts and largely dependent on relationships and trust. The profitability varies up to about $2 \%$ of the total profit, but too often it is a zero sum game according to the CEO. Even if the farmers today pay a price reflecting a corresponding mineral fertilizer value of the biofertilizer, it is often "eaten up" by the costly transportation and distribution due to the large water content. Like other biogas companies, the PBC works on finding ways to valorise the digestate, but so far they only have one really successful case. A small local herb seed producing company buys digestate since they need eco-certified soil. This is a small cooperation in terms of mass but not negligible in terms of money and it is a win-win concept according to the CEO.

For the three plants conditions vary. Two of them are based on feedstock for which the economic driver was rated low by the PBC, e.g., distillers spent grain, starch and ley crop. This is explained by low margins related to these flows, due to the price the PBC pays. However, the cooperation exists because it was the best available feedstock when the 
contracts were signed. In comparison, there are stronger economic incentives to utilize manure and slaughterhouse waste, not paid for. The business model of the PBC seems to create stable cooperation although the economic driver for many of the flows is rather low.

Looking at the environmental driver it is rated as medium or high for all cooperative relations, except for the ley crop. Clearly, the RED policy largely influences how the CEO judges the environmental drivers. The respondent were of the opinion that this policy fails to account for all relevant environmental aspects related to the use of ley crops, saying that it would have been rated higher from an environmental perspective if the RED did not have such influence. Cooperation characterized by both low economic and environmental drivers, such as ley crops, might be seen as economically unsustainable unless the policy framework is changed.

\section{Concluding discussion}

\section{Status of connectedness}

It can be concluded that the studied biofuel production systems involve many cooperating actors, including several suppliers of raw material and energy, and several customers. There are not only customers for the main products, but also for by-products such as thin stillage and glycerol used for biogas production, and digestate/biofertilizers used by farmers and an herb seed producer. Knowledge about the described physical flows is valuble and the cases include material and energy exchanges between traditionally separate industries, commonly in focus within the IS field (Chertow, 2000, van Beers et al., 2007).

It is essential for all the biofuel producers to have well-established relations with actors in the agricultural sector, including farmers. Well-functioning cooperation is needed for input of agricultural feedstock and farmers may be buyers of both fodder and biofertilizers. Both on the input and output side, this study showed examples of contracts directly with individual farmers but also solutions where farmers had to form a corporation or a consultancy firm was used to deal with farmers. The food and feed industry are examples of other relevant sectors that are interacting with the studied biofuel companies, providing inputs or receiving outputs.

Cooperation regarding utilities is also found in the study. Utilization of heating or cooling, based on a large share of renewables, was the most common form of cooperation, found in all companies.

While ethanol production requires carbohydrates or lignin and biodiesel requires triglycerides, biogas can be produced from both these hydrocarbons and proteins (cf. Ersson et al., 2013). Thus biogas solutions allow greater flexibility on the input side (Börjesson et al., 2013, Lantz et al., 2007). All the biogas plants utilize several feedstock categories, chosen considering aspects such as co-digestion effects and prices. The flows vary regarding volume/importance and some are linked to individual industries while others involve a large number of actors. In contrast, the EC and BDC have one major feedstock on the input side, cereals and rapeseed oil respectively. In the BDC this is based on cooperation with one actor while the EC case involves extensive cooperation with local cereal producers.

Three of the companies, the biodiesel and biogas producers, have mainly one by-product flow. While the glycerol (BDC) is valuable, the biogas companies struggle to make profit from the biofertilizers, which seems to be a common problem in this sector (cf. Berglund, 2006, Dolan et al., 2011). The EC have two valuable by-product flows, fodder and stillage. 


\section{Dynamics in connectedness}

Clearly, the connectedness can be described as dynamic, although the studied companies are rather newly established. Interesting development was noted for all the biofuel producers, where revised business strategies have led to developed cooperation structures and thus changed material and energy flows. The companies have taken advantage of opportunities and adopted strategies to cope with challenges in order to stay, or become, competitive. According to their present plans this dynamic strategy will continue - ongoing development is expected.

Comparing the different types of exchanges, the cooperation on by-products appears most dynamic, especially when there is no shared infrastructure for the exchange. By-product exchanges seem to follow the pattern of common trade, where market conditions induce changing patterns. All the companies focus on valorisation of the by-products, for example, increasing the value of the biofertilizers or considering alternative options for glycerol. The ethanol producer both considered differentiation and valorisation, to more efficiently make use of the protein content in the stillage, with a development from one to several and more valuable fodder products. This “biorefinery development” (cf. Octave and Thomas, 2009) could increase the income from fodder, increasing its relative importance to the ethanol from an economic perspective.

The exchanges of byproducts between the biofuel companies will potentially cease or decrease if the valorisation efforts are fully implemented, because alternative options are more favourable from an economic perspective, related to the prices the biogas producers are willing to pay. Both of the biogas producers strive to lower costs for raw material in order to stay competitive (cf. Barney, 2007), i.e. to intensify the search for low-cost substrates. Due to the flexibility of biogas production (Lantz et al., 2007) such changes of feedstock are possible, but also imply technological challenges and have impact on the quality of the biofertilizers. According to the respondents, low-cost substrates like manure, food waste, etc., often have a lower energy content and/or require costly pretreatment, making them less cost efficient than high-quality substrates. Nevertheless, biogas solutions might close the loops of many organic flows in society in line with the waste hierarchy (European Parliament, 2008) and industrial ecology thinking. Biogas technology has been termed an "upcycling tenant" in industrial symbiosis terminology (Martin, 2010) since it has the capacity to upgrade low-quality substrates to valuable products such as fuel and biofertilizers. The PBC's strategy was to reduce long-term contracts on feedstock to increase flexibility. In the MBC, focus has shifted towards feedstock internally available within the corporate group, controlled by a monopoly, such as food waste separated from household waste.

Naturally, the EC and BDC also have the ambition to use low-cost feedstock, but their specificity in feedstock requirements (cf. Cherubini, 2010) leaves less room for flexibility. The resource efficiency and cost reduction in wheat ethanol production can be substantially improved but mainly involves change of practices among many farmers (cf. Tilman et al., 2002). As feedstock makes up about $75-80 \%$ of the costs for ethanol production this is of utmost importance. The option to start utilizing ethanol wheat was mentioned (noted as a general option for ethanol producers in Börjesson et al. 2013). Used cooking oils are possible future low-cost substrates that would improve the environmental performance for the BDC. However, the demand and cost for this feedstock have increased according to the CEO.

It can also be concluded that the type of cooperation sometimes referred to as "utility synergies" in literature (e.g. heating and cooling cooperation) seems to be more stable than others, which has also been confirmed by van Beers et al. (2007). However, some relevant 
changes were noted, such as the expanded use of steam by the ethanol producer in cooperation with a power company and the biogas company using district heating for upgrading.

\section{Critical factors influencing connectedness}

In addition to the information about the physical metabolism, the respondents provided information about important drivers and barriers influencing the development, sometimes referred to as the "social metabolism" (e.g. Schiller et al., 2014). For example, economic, institutional, social and cultural aspects are influential and impact on the decision-making processes of the actors that could potentially exchange material, energy and information (Domenech and Davies, 2009).

Naturally, economic factors were frequently mentioned by the CEOs. The companies strive towards cost efficient raw material and energy supply solutions, to increase the value of their products and the number of (by-) products (valorisation and diversification), and they are influenced by the needed investments and try to make use of investments made (e.g. existing infrastructure), etc. Regarding by-product exchanges, short-term economic drivers seem most influential. The EC initially focused on economy of scale, to benefit from large-scale production, which is a strategy that is acknowledged in the biofuel industry (cf. van den Wall Bake et al., 2009, Hettinga et al., 2009) and in business more generally (Panzar and Willig, 1977). However, this focus on the main product leads to "simpler" solutions for by-products, like using residual heat for DDGS production from the stillage and shipping thin stillage to the neighbouring biogas plant (and other more common waste handling solutions). This changed when more attention was paid to the options to diversify and valorise the by-products and these appeared promising from an economic perspective, which can be described as a shift towards economy of scope (Panzar, 1981). Similar ambitions to use the economy of scope strategy were identified for all companies. However, for the BDC the supplying vegetable oil refinery controls the primary raw material. Further on, it is urgent for the MBC and $\mathrm{PBC}$ to generate more income from the digestate representing a valuable part of the biogas production system. All of the respondents mentioned challenges in relation to profitability, where for example the economic competitiveness of the Swedish biofuel industry generally is lower than the Brazilian which according to van den Wall Bake et al. (2009) is one of the few such industries without any subsidies.

Within the biofuel industry there is an ongoing policy expansion influencing the development. Policy is very influential, in many ways also directly or indirectly affecting the economic incentives mentioned. For some of the described development institutional factors have been drivers, for example, the EU Renewable Energy Directive (RED, EU RES, 2009) where Swedish tax exemptions coupled to RED (see e.g. Ahlgren, 2012) influence choices regarding raw materials, by-product management and other issues. For other types of cooperation or exchanges, policy hinders or at least limits the development, for example, the possibilities to certify biofertilizers from biogas production.

The RED was commonly mentioned as important for the industry, but it should be noted that all studied companies already meet the current requirements of that directive with good margins. Regarding the described feedstock development for the biogas producers, this directive seems to have minor influence. Instead the MBC and PBC referred to prices and political goals such as objectives for energy and nutrient recovery in waste treatment as important drivers (see Miljömålsportalen, 2014). One of the CEOs argued that the benefits of 
using ley crops for biogas production is not correctly valued in the RED, and should be regarded as more beneficial if additional aspects of sustainability were encountered.

The companies were involved with strategies that could be described as waste refinery and biorefinery concepts, where valuable products are refined from waste or biomass. This is highly relevant from a resource efficiency and environmental perspective. The use of byproducts and waste for biofuel production is promoted by the RED, but its allocation method for environmental impact may function as a barrier for by-product exchanges. For example, internal refining of the glycerol in the BDC would (accounted in accordance with RED) improve the GHG emission reduction of their biodiesel by 7-8\%, compared to the current use for biogas production. The drivers are similar for the EC's thin stillage, currently used for biogas production. It can be concluded that RED clearly favours diversification and valorisation ahead of simple by-product exchanges which influences the studied companies. This, once again, illustrates that environmental regulatory structures can both hinder and facilitate industrial symbiosis.

Political decisions to a large extent affect the companies' competitiveness and the importance of clear long-term institutional conditions was emphasised. On the contrary, the institutional landscape within EU appears very uncertain for biofuel producers, partly because there is an ongoing revision of the RED and other related regulations. The European Commission has proposed some amendments, for example, to try limit the share of crop-based biofuels and to make it mandatory to account for and declare (hypothetically existing) emissions related to indirect land use changes (iLUC, EU RES, 2012, EP, 2013; Ahlgren and Di Lucia, 2014). This kind of development is problematic for the biofuel industry. If the proposal is realised, for example, biofuels from oil crops will be affected to a large extent due to a generic ILUC emission addition of $55 \mathrm{~g} \mathrm{CO}_{2}$-eq/MJ of biodiesel (ibid.). It surely is a challenge to establish relevant legislation and other types of means of control for biofuels, but if the main ambition is to secure levels of food and fodder production, and to improve the environmental situation, policy makers must apply a much wider systems perspective including competing alternatives and uses. An tough regulation of biofuels will favour fossil fuels with many types of significant negative impacts (also affecting food and fodder supply potentials). Comparing different types of needs, food, fodder and fuels (transportation) should have a higher priority than, for example, cosmetics, lemonades, etc., that can be based on the same type of resources but in this respect are rather unregulated and not under debate.

Closely coupled to economic and policy considerations, the CEOs referred to several types of environmental factors when describing the reasons behind their companies' development. Environmental drivers strongly influenced the cooperation regarding green heating, found in all companies. For example, the access to a green and stable energy supplier had major impact on the decision of where to locate ethanol production, highlighting the importance of the characteristics of the energy supply for biofuel producers (cf. Desrochers, 2004). This seems reasonable, as the characteristics of the energy system have a major influence on the environmental performance of biofuels (Börjesson, 2009). By-products from biofuel production serve as important feedstock for biogas production, which also improves environmental performance of the biofuels produced (Martin \& Eklund, 2011). Sometimes, by-product utilization improves the environmental performance of the fuel without corresponding improvement of the economic performance as in the case of biogas digestate used as biofertilizer. In terms of GHG emission reduction compared to petrol, the companies perform significantly better than presently required by RED where the EC reaches about $70 \%$ reduction, which is similar to Brazilian sugar cane ethanol (Börjesson, 2009). Regarding 
biogas produced from waste and agricultural by-products, the GHG reduction is even better. With no more than about 10-15 years of learning experience among niche actors this industry is already among the best in this regard on the biofuel market, but they still have ambitions to continue to improve their environmental performance even if the short-term profitability is low. The respondents described a substantial pressure both from policy and the market to deliver high-quality products competitively priced and simultaneously contribute to sustainability. In order to improve they are looking at the structure of relationships both upstream along their supply chain as well as downstream towards the customer interface for opportunities that could contribute to their economic as well as environmental performance. Due to expectations and requirements of embedded values of sustainability in the products, these values are to some extent transferred into business models which could be seen as a useful tool in an eco-innovation process for biofuel producers (cf. Boons and Lüdeke-Freund, 2013). The $\mathrm{CO}_{2}$ cooperation project of the EC is driven by the ambitions to meet GHG reductions that go far beyond the current and foreseeable requirements in the RED. This proactive approach "being ahead" of policy could probably be referred to as environmental branding which is important in this industry.

Further on, the respondents confirmed that social relations, including trust, are factors that influence development of cooperation projects and investments in shared infrastructure function as a driver to maintain or even expand the cooperation. Relations seem to develop between representatives within the biofuel sector that could strengthen such cooperation projects. Possibly, small-scale biofuel producers typically represent small resources which may drive the quest for different partnerships. Also, knowledge-based synergies on an intrafirm and inter-firm level were stated to play an important role. Within the corporate group of the EC, their competence was mobilized to find innovative ways to diversify and valorise the fodder products. Similarly, a development towards more knowledge-based synergies was observed in the biogas companies such as investments in research ventures for eco-innovation with academia, farmers' organizations and others regarding digestate handling and valorisation. These observed knowledge-based synergies relate to the definition of industrial symbiosis as an innovation phenomenon (Lombardi and Laybourn, 2012). In some of the companies cooperation in relation to the consumers/market was also found in order to reach an established network/sales organization as well as competency in this area which could also be regarded as important in order to organize a competitive production.

While there has been a consensus in IS literature that IS improves competitiveness, most often through improved natural resource efficiency, the opportunities of IS should however be regarded as much broader (Lombardi and Laybourn, 2012). Hence, when looking at critical factors for IS in the biofuel industry this must be taken into consideration in order to better understand barriers and drivers for cooperation from the actors' perspective. Because of both policy and customer pressure on the biofuel industry to deliver sustainable biofuels, the value embedded in the product/services relates to the whole life cycle of biofuels, which is why supply chain management as well as the customer interface are important parts of future business models for sustainable innovation.

\section{Future outlook}

The EU growth strategy involves a transformation into a "greener", bio-based economy, seen as necessary to move towards more sustainable development (European Commission, 2011). As a part of this, there are high expectations on future biorefineries to deliver a valuable array of products in a resource-efficient way, and biorefinery concepts get a lot of attention in the research policy context. However, how the future biorefineries will be realized is not obvious. 
A revolutionary development is possible, where big investments are made and many new biorefineries are built. On the other hand, innovation research often criticizes such simple linear innovation and development models, where research should lead to inventions that later are supposed to be demonstrated, commercialized, and diffused (Freeman, 1996). Instead, a more dynamic model involving feedback loops and intervention of different actors is seen as more realistic (Lybæk et al., 2012). Possibly, there is already an ongoing evolution of existing biofuel production into biorefinery networks, where existing biofuel industries develop their operations towards increased valorisation, productification and diversification. In that case, ongoing business-driven processes might contribute to a trajectory of more resource efficient use of biomass. Possibly, it also represents a more realistic, evolutionary or stepwise development into biorefineries (Kram, 2007) that can vitalize innovation in existing industries (Wellisch et al., 2010).

In this study, the development that was found in the EC and BDC may contribute to improved economic and environmental performance, i.e., similar to the biorefinery idea (cf. Fatih Demirbas, 2009). Additionally such diversification potentially increases the resilience which according to Mu et al. (2010) is particularly important for biofuel production systems. There are many examples outlined in literature of complex and resilient biofuel production systems (cf. Hatti-Kaul et al., 2007, Taylor, 2008, Octave and Thomas, 2009). However, the experience of actually producing biofuels has been suggested to provide better competitiveness relative to technologies only developed in research and development labs (Suurs and Hekkert, 2009). Stepwise development might also better incorporate transformability in the design of new technology and a readiness to change which may further contribute to resilience (cf. Mu et al., 2011).

Existing biofuel production systems seem to contain dynamic transformability and openness to adapt which is a key to future competitive advantage, improved resource efficiency and a development kernel for the biorefineries of the future.

\section{Acknowledgement}

This research has partially been funded by the Swedish Biogas Research Center (BRC), in turn being funded by the Swedish Energy Agency. Some of the funding is also from the Industrial Ecology Research Program (IERP), a collaboration between Linköping university and Tekniska Verken i Linköping AB.

\section{References}

AHLGREN, S., 2012. Sustainability criteria for biofuels in the European Union - A Swedish perspective (No. f3 2012:2)

AHLGREN, S., DI LUCIA, L., 2014. Indirect land use changes of biofuel production - a review of modelling efforts and policy developments in the European Union. Biotechnology for Biofuels 2014.

BARNEY, J., CLARK, D., 2007. Resource-Based Theory, Creating and Sustaining Competitive Advantage, New York, Oxford University Press.

BERGEK, A. 2002. Shaping and Exploiting Technological opportunities: The Case of Renewable Energy Technology in Sweden. Ph D, Chalmers Univeristy of Technology.

BERGLUND, B., ERSSON C., EKLUND M., MICHAEL M. 2011. Challenges for developing a system for biogas as vehicle fuel - lessons from Linkoping, Sweden. World Renewable Energy Congress 2011 Linköping, Sweden. 
BERGLUND, M. 2006. Biogas Production from a Systems Analytical Perspective. Ph D, Lund University.

BOONS, F. 1998. Caught in the web: the dual nature of networks and its consequences. Business Strategy and the Environment, 7, 204-212.

BOONS, F. \& LÜDEKE-FREUND, F. 2013. Business models for sustainable innovation: state-of-the-art and steps towards a research agenda. Journal of Cleaner Production, 45, 9-19.

BOONS, F., SPEKKINK, W. \& MOUZAKITIS, Y. 2011. The dynamics of industrial symbiosis: a proposal for a conceptual framework based upon a comprehensive literature review. Journal of Cleaner Production, 19, 905-911.

BP 2012. BP Energy Outlook 2030. London: British Petroleum Company.

BÖRJESSON, P. 2009. Good or bad bioethanol from a greenhouse gas perspective - What determines this? Applied Energy, 86, 589-594.

CHERTOW, M. R. 2000. Industrial symbiosis: Literature and taxonomy. Annual Review of Energy and the Environment, 25, 313-337.

CHERUBINI, F. 2010. The biorefinery concept: Using biomass instead of oil for producing energy and chemicals. Energy Conversion and Management, 51, 1412-1421.

DEMIRBAS, A. 2009. Political, economic and environmental impacts of biofuels: A review. Applied Energy, 86, S108-S117.

DESROCHERS, P. 2004. Industrial symbiosis: The case for market coordination. Journal of Cleaner Production, 12, 1099-1110.

DOLAN, T., COOK, M. B. \& ANGUS, A. J. 2011. Financial appraisal of wet mesophilic AD technology as a renewable energy and waste management technology. Science of The Total Environment, 409, 2460-2466.

DOMENECH, T., DAVIES, M., 2009. The social aspects of industrial symbiosis: the application of social network analysis to industrial symbiosis networks. Progress in Industrial Ecology, an International Journal 6, 68-99.

EP, 2013. European Parliament legislative resolution of 11 September 2013 on the proposal for a directive of the European Parliament and of the Council amending Directive 98/70/EC relating to the quality of petrol and diesel fuels and amending Directive 2009/28/EC on the promotion of the use of energy from renewable sources, First reading. Brussels: European Parliament; 2013

ERSSON, C., AMMENBERG, J. \& EKLUND, M. 2013. Biofuels for transportation in 2030: Feedstock and production plants in a Swedish county. Biofuels, 4, 379-395.

EU RES 2009. Directive 2009/28/EC of the European Parliament and of the Council of 23 April 2009 on the promotion of the use of energy from renewable sources and amending and subsequently repealing Directives 2001/77/EC and 2003/30/EC.

EU RES 2012. Proposal for a Directive of the European Parliament and of the Council amending Directive 98/70/EC relating to the quality of petrol and diesel fuels and amending Directive 2009/28/EC on the promotion of the use of energy from renewable sources. European Parliament.

EUROPEAN COMMISSION 2011. Energy roadmap 2050.

EUROPEAN PARLIAMENT, C. 2008. Directive 2008/98/EC of the European Parliament and of the Council of 19 November 2008 on waste and repealing certain Directives (Text with EEA relevance. COD(2005)0281. EUR-Lex: European Commission.

EUROSTAT. 2013. Statistics database [Online]. European Commission. Available: http://epp.eurostat.ec.europa.eu/portal/page/portal/statistics/search_database [Accessed 9th of October 2013.

EXXON MOBIL 2013. The outlook for energy - a view to 2040.

FALLDE, M. 2011. Miljö i tanken? PhD, Linköping university. 
FATIH DEMIRBAS, M. 2009. Biorefineries for biofuel upgrading: A critical review. Applied Energy, 86, Supplement 1, S151-S161.

FREEMAN, C. 1996. The greening of technology and models of innovation. Technological Forecasting and Social Change, 53, 27-39.

HARDY, C. \& GRAEDEL, T. E. 2002. Industrial Ecosystems as Food Webs. Journal of Industrial Ecology, 6.

HATTI-KAUL, R., TÖRNVALL, U., GUSTAFSSON, L. \& BÖRJESSON, P. 2007. Industrial biotechnology for the production of bio-based chemicals - a cradle-to-grave perspective. Trends in Biotechnology, 25, 119-124.

HETTINGA, W. G., JUNGINGER, H. M., DEKKER, S. C., HOOGWIJK, M., MCALOON, A. J. \& HICKS, K. B. 2009. Understanding the reductions in US corn ethanol production costs: An experience curve approach. Energy Policy, 37, 190-203.

IGLIŃSKI, B., BUCZKOWSKI, R., IGLIŃSKA, A., CICHOSZ, M., PIECHOTA, G. \& KUJAWSKI, W. 2012. Agricultural biogas plants in Poland: Investment process, economical and environmental aspects, biogas potential. Renewable and Sustainable Energy Reviews, 16, 4890-4900.

KARLSSON, M. \& WOLF, A. 2008. Using an optimization model to evaluate the economic benefits of industrial symbiosis in the forest industry. Journal of Cleaner Production, $16,1536-1544$.

KRAM, J. W. 2007. The elusive biorefinery. Biomass Magazine Power and Thermal [Online]. Available: http://biomassmagazine.com/articles/1231/the-elusive-biorefinery [Accessed 24th of October 2013].

KUCHLER, M. \& LINNÉR, B. O. 2012. Challenging the food vs. fuel dilemma: Genealogical analysis of the biofuel discourse pursued by international organizations. Food Policy, 37, 581-588.

LANTZ, M., SVENSSON, M., BJÖRNSSON, L. \& BÖRJESSON, P. 2007. The prospects for an expansion of biogas systems in Sweden-Incentives, barriers and potentials. Energy Policy, 35, 1830-1843.

LOMBARDI, D. R. \& LAYBOURN, P. 2012. Redefining Industrial Symbiosis. Journal of Industrial Ecology, 16, 28-37.

LYBÆK, R., CHRISTENSEN, T. B. \& KJÆR, T. 2012. Governing Innovation for Sustainable Development in the Danish Biogas Sector - a Historical Overview and Analysis of Innovation. Sustainable Development, n/a-n/a.

MARTIN, M. 2010. Industrial Symbiosis for the Development of Biofuel Production. Licentiate thesis, Linköping University.

MARTIN, M. 2013. Industrial Symbiosis in the Biofuel Industry: Quantification of the Environmental Performance and Identification of Synergies. PhD dissertation, Linköping University.

MARTIN, M. \& EKLUND, M. 2011. Improving the environmental performance of biofuels with industrial symbiosis. Biomass and Bioenergy, 35, 1747-1755.

MILJÖMÅLSPORTALEN. 2014. Regeringens etappmål för ökad resurshushållning i livsmedelskedjan [Online]. Swedish Environmental Protection Agency. Available: http://miljömål.se/sv/Hur-nar-vi-malen/Avfall/Okad-resurshushallning-ilivsmedelskedjan/ [Accessed 21st of February 2014].

MU, D., SEAGER, T. P., RAO, P. S. C., PARK, J. \& ZHAO, F. 2011. A Resilience perspective on biofuel production. Integrated Environmental Assessment and Management, 7, 348-359.

MU, D., ZHAO, F., SEAGER, T., RAO, S., 2010. Integration of resilience perspective into sustainability assessment of biofuel production. International design Engineering 
Technical Conference \& Computers and Information in Engineering Conference. Montreal: ASME.

OCTAVE, S. \& THOMAS, D. 2009. Biorefinery: Toward an industrial metabolism. Biochimie, 91, 659-664.

OECD/FAO 2012. OECD-FAO Agricultural Outlook 2012-2021,.

PANZAR, J. C. \& WILLIG, R. D. 1977. ECONOMIES OF SCALE IN MULTI-OUTPUT PRODUCTION. Quarterly Journal of Economics, 91, 481-493.

PANZAR, J. C., WILLIG, R. D., 1981. Economies of Scope. The American Economic Review, 71, 268-272.

ROSEGRANT, M.W., MSANGI, S., 2014. Consensus and Contention in the Food-VersusFuel Debate. Annual Review of Environment and Resources 39, 271-294. doi:10.1146/annurev-environ-031813-132233

RUTH, M. \& DAVIDSDOTTIR, B. 2009. The dynamics of regions and networks in industrial ecosystems : background and concepts. The Dynamics of Regions and Networks in Industrial Ecosystems. Edward Elgar Publishing.

SCHILLER, F., PENN, A.S., BASSON, L., 2014. Analyzing networks in industrial ecology a review of Social-Material Network Analyses. Journal of Cleaner Production 76, 111. doi:10.1016/j.jclepro.2014.03.029

SUURS, R. A. A. \& HEKKERT, M. P. 2009. Competition between first and second generation technologies: Lessons from the formation of a biofuels innovation system in the Netherlands. Energy, 34, 669-679.

SVEBIO 2012. Tillväxt hotas av nytt regelverk. Tidningen Bioenergi 2012:5. Svebio.

SWEDISH ENERGY AGENCY 2012. Hållbara biodrivmedel och flytande biobränslen under 2011. Swedish Energy Agency.

TAYLOR, G. 2008. Biofuels and the biorefinery concept. Energy Policy, 36, 4406-4409.

TILMAN, D., CASSMAN, K. G., MATSON, P. A., NAYLOR, R. \& POLASKY, S. 2002. Agricultural sustainability and intensive production practices. Nature, 418, 671-677.

VAN BEERS, D., BOSSILKOV, A., CORDER, G. \& VAN BERKEL, R. 2007. Industrial Symbiosis in the Australian Minerals Industry: The Cases of Kwinana and Gladstone. Journal of Industrial Ecology, 11, 55-72.

VAN DEN WALL BAKE, J. D., JUNGINGER, M., FAAIJ, A., POOT, T. \& WALTER, A. 2009. Explaining the experience curve: Cost reductions of Brazilian ethanol from sugarcane. Biomass and Bioenergy, 33, 644-658.

WELLISCH, M., JUNGMEIER, G., KARBOWSKI, A., PATEL, M. K. \& ROGULSKA, M. 2010. Biorefinery systems-potential contributors to sustainable innovation. Biofuels, Bioproducts and Biorefining, 4, 275-286.

WRIGHT, R. A., CÔTÉ, R. P., DUFFY, J. \& BRAZNER, J. 2009. Diversity and Connectance in an Industrial Context. Journal of Industrial Ecology, 13, 551-564.

ZHU, J. \& RUTH, M. 2013. Exploring the resilience of industrial ecosystems. Journal of Environmental Management, 122, 65-75. 